\title{
FAKTOR - FAKTOR YANG MEMPENGARUHI PENGURANGAN PAJAK SECARA AGRESIF
}

\author{
Indira Shinta Dewi, SE., MM., Ak \\ indiradewi20@gmail.com
}

Fakultas Ekonomi - Program Studi Akuntansi

Universitas Satya Negara Indonesia

\begin{abstract}
ABSTRAK
Penelitian ini bertujuan untuk menguji pengaruh kepemilikan manajerial, kepemilikan institusional dan likuiditas terhadap agresivitas pajak. Populasi dalam penelitian ini adalah perusahaan manufaktur yang terdaftar di Bursa Efek Indonesia (BEI) pada tahun 2015-2017. Sampel penelitian ini dipilih dengan menggunakan metode purposive sampling, terdapat 113 sampel pengamatan yang memenuhi kriteria. Penelitian ini menggunakan uji regresi linier berganda untuk mengetahui pengaruh dari kepemilikan manajerial, kepemilikan institusional dan likuiditas terhadap agresivitas pajak. Hasil penelitian ini menunjukkan bahwa likuiditas tidak berpengaruh terhadap agresivitas pajak . Sedangkan kepemilikan manajerial dan kepemilikan institusional berpengaruh terhadap agresivitas pajak.
\end{abstract}

Kata kunci: Kepemilikan manajerial, kepemilikan institusional, likuiditas dan agresivitas pajak 


\section{PENDAHULUAN}

Teori agency menjelaskan adanya konflik yang akan timbul antara pemilik dan manajemen perusahaan (Jensen \& Meckling, 1976). Adanya pemisahan antara pemilik dengan manajemen perusahaan dapat menimbulkan masalah. Agresivitas pajak dipengaruhi oleh adanya konflik kepentingan antara agen (manajemen) dengan kepentingan yang timbul ketika setiap pihak berusaha untuk mencapai atau mempertahankan tingkat kemakmuran yang dikehendakinya. Perusahaan yang melakukan agresivitas pajak tentu saja juga melalui kebijakan yang diambil oleh manajemen perusahaan guna membangun citra baik perusahaan serta melakukan mencapai laba yang maksimal .

Agresifnya perusahaan terhadap tindakan-tindakan yang dilakukan untuk mengurangi kewajiban pajak bertujuan untuk meminimalkan beban pajak dengan cara memanfaatkan celah ketentuan perpajakan suatu negara. Skema penghindaran pajak bersifat legal atau sah tidak melanggar ketentuan perpajakan. Praktik penghindaran pajak umumnya dilakukan dengan memanfaatkan adanya perbedaan regulasi perpajakan yang dirancang sedemikian rupa agar tidak melanggar ketentuan pajak secara resmi .

Menurut Frank et.al (2009) perencanaan pajak dengan tujuan merekayasa laba kena pajak berupa tax avoidance atau tax evasion merupakan salah satu tindakan pajak secara agresif, agresivitas pajak tersebut dapat diukur dengan Effective Tax Rate (ETR). Penelitian ini menggunakan ETR untuk mengukur pengurangan pajak secara agresif.

Menurut Frank et.al (2009) perencanaan pajak dengan tujuan merekayasa laba kena pajak berupa tax avoidance atau tax evasion merupakan salah satu tindakan pajak secara agresif, agresivitas pajak tersebut dapat diukur dengan Effective Tax Rate (ETR). Penelitian ini menggunakan ETR untuk mengukur pengurangan pajak secara agresif. Effective Tax Rate (ETR) merupakan rasio dari pajak yang dibayarkan perusahaan berdasarkan beban pajak terhadap laba sebelum pajak.

Hasil penelitian Indrajati et al. (2015) menjelaskan bahwa likuiditas memiliki pengaruh negatif terhadap agresivitas pajak, meningkatnya nilai likuiditas perusahaan akan menurunkan nilai ETR . Effective tax rate (ETR) juga dipengaruhi oleh struktur kepemilikan perusahaan. Struktur kepemilikan perusahaan terdiri dari kepemilikan manajerial dan kepemilikan institusional. Penelitian yang dilakukan oleh Rahati (2015) menyatakan bahwa kepemilikan manajerial berpengaruh terhadap tarif pajak efektif. Kepemilikan institusional akan mempengaruhi perusahaan agar lebih agresif dalam upaya memaksimalkan laba setelah pajak, sehingga pihak institusi sebagai pemegang saham akan fokus pada kinerja jangka pendek yang mendorong manajer membuat keputusan untuk meningkatkan laba jangka pendek (Khurana dan Moser, 2009). 


\section{Rumusan Masalah}

Berdasarkan latar belakang diatas, maka masalah yang akan dibahas dalam penelitian ini adalah sebagai berikut:

1. Apakah kepemilikan managerial berpengaruh terhadap agresivitas pajak?

2. Apakah kepemilikan institusional berpengaruh terhadap agresivitas pajak?

3. Apakah likuiditas berpengaruh terhadap agresivitas pajak?

\section{Tujuan Penelitian}

Berdasarkan rumusan masalah diatas, tujuan dari penelitian ini adalah :

1. Mendapatkan bukti empiris tentang pengaruh kepemilikan managerial terhadap agresivitas pajak.

2. Mendapatkan bukti emperis tentang pengaruh kepemilikan institusional terhadap agresivitas pajak.

3. Mendapatkan bukti emperis tentang pengaruh likuiditas terhadap agresivitas pajak.

\section{Manfaat Penelitian}

Penelitian ini diharapkan dapat memberikan manfaat kepada :

1. Pengembangan teori

Penelitian ini berkontribusi pada pengambangan teori keagenan yang berhubungan dengan agresivitas pajak.

2. Pemerintah

Pemerintah dapat membuat acuan tentang kebijakan agresivitas pajak.

\section{TINJAUAN PUSTAKA}

\section{Teori Agency}

Menurut Jensen and Meckling 1976 teori agensi merupakan konflik yang akan terjadi antara pemilik perusahaan dan manajemen perusahaan. Konflik terjadi karena adanya perbedaan kepentingan antara pemilik dengan manajemen perusahaan . Setiap pihak berusaha untuk mencapai atau mempertahankan tingkat kemakmuran yang dikehendakinya. Perbedadan kepentingan ini dapat menimbulkan agresivitas pajak. Perusahaan yang melakukan agresivitas pajak tentu saja juga melalui kebijakan yang diambil oleh manajemen perusahaan guna membangun citra baik perusahaan serta melakukan mencapai laba yang maksimal.Sedangkan bagi pemilik perusahaan 
(investor) tidak menghendaki adanya agresvitas pajak karena dianggap memanipulasi data laporan keuangan.

Rahmawati (2012:97) hubungan agensi (agency relationship) terjadi saat pemilik perusahaan mengontrak agen (agent) atau mempekerjakan manajer untuk mendelegasikan wewenang pengambilan keputusan kepadanya dan memberikan jasanya. Hubungan ini dapat menimbulkan konflik antara pemilik perusahaan dengan manajer yang menjalankan perusahaan.

\section{Pengertian Pajak}

Undang Undang Nomor 28 Tahun 2007 pasal 1 ayat 1 tentang Ketentuan Umum dan Tata Cara Perpajakan menjelaskan bahwa pajak adalah

Kontribusi wajib kepada negara yang terutang oleh orang pribadi atau badan yang bersifat memaksa berdasarkan undang-undang dengan tidak mendapatkan imbalan secara langsung dan digunakan untuk keperluan negara bagi sebesarbesarnya kemakmuran rakyat.

Sedangkan definisi pajak yang dikemukakan oleh Prof. Dr. Rochmat Soemitro dalam Mardiasmo (2016:1) pajak adalah:

Iuran rakyat kepada kas negara berdasarkan undang-undang (yang dapat dipaksakan) dengan tiada mendapat jasa timbal balik (kontrapestasi) yang langsung dapat ditunjukkan dan digunakan untuk membayar pengerluaran umum.

\section{Agresivitas Pajak}

Perusahaan menganggap pajak sebagai sebuah tambahan biaya yang dapat mengurangi keuntungan perusahaan. Oleh karena itu perusahaan diprediksi melakukan tindakan yang akan mengurangi beban pajak perusahaan. Menurut Frank dkk. (2009), tindakan yang dilakukan perusahaan untuk mengurangi pendapatan kena pajak melalui perancanaan pajak baik secara legal (tax avoidance) maupun ilegal (tax evasion) disebut dengan agresivitas pajak perusahaan. Walaupun tidak semua tindakan perencanaan pajak melanggar hukum, akan tetapi semakin banyak celah yang digunakan maka perusahaan tersebut dianggap semakin agresif. Frank et.al. (2009) menyatakan tindakan pajak agresif adalah suatu tindakan yang bertujuan untuk merekayasa laba kena pajak perusahaan melalui perencanaan pajak. Agresivitas pajak dapat diukur dengan berbagai cara, yaitu dengan menggunakan Effective Tax Rate (ETR), Book Tax Difference (BTD), Residual Tax Difference (RTC), dan Cash Effective Tax Rate (CETR).

\section{Effective Tax Rate}

Effective tax rate (ETR) dihitung atau dinilai berdasarkan pada informasi keuangan yang dihasilkan oleh perusahaan sehingga effective tax rate (ETR) merupakan bentuk perhitungan tarif pajak pada perusahaan. Effective tax rate 
seringkali digunakan sebagai pengukuran efektivitas perencanaan pajak suatu perusahaan ataupun untuk mengukur penghindaran pajak yang dilakukan oleh perusahaan

Effective tax rate (ETR) dihitung dari beban pajak penghasilan dibagi dengan pendapatan sebelum pajak. Semakin baik nilai effective tax rate (ETR) ditandai dengan semakin rendahnya nilai effective tax rate (ETR) perusahaan tersebut.

\section{Kepemilikan Manajerial}

Kepemilikan manajerial merupakan proporsi kepemilikan saham yang dimiliki oleh manajemen suatu perusahaan.Persentase suara yang berkaitan dengan saham dan option yang dimiliki oleh manajer dan komisaris suatu perusahaan. Kepemilikan manajerial merupakan salah satu cara untuk mengurangi masalah keagenan, hal ini dikarenakan kepemilikan manajerial merupakan alat pengawasan terhadap kinerja manajer yang bersifat internal.

Semakin besar proporsi kepemilikan manajerial dalam perusahaan maka manajemen akan berusaha lebih giat untuk kepentingan pemegang saham yang notabene adalah mereka sendiri.

\section{Kepemilikan Institusional}

Kepemilikan institusional adalah kepemilikan saham perusahaan yang dimiliki oleh institusi atau lembaga seperti perusahaan asuransi, bank, perusahaan investasi dan kepemilikan lain. Kepemilikan institusional dalam struktur kepemilikan memiliki peran monitoring management, kepemilikan institusional merupakan pihak yang paling berpengaruh dalam pengambilan keputusan karena sifatnya sebagai pemilik saham mayoritas. Kepemilikan institusional menurut Rachmawati dan Triatmoko (2014) .Semakin tinggi kepemilikan oleh pihak institusional maka akan semakin kuat eksternal control terhadap perusahaan, karena investor institusional disinyalir akan mendorong adanya peningkatan pengawasan yang lebih optimal terhadap kinerja manajemen perusahaan, sehingga kinerja perusahaan pun akan meningkat.

\section{Likuiditas}

Menurut Hery (2016:149) Rasio likuiditas adalah rasio yang menunjukkan kemampuan perusahaan dalam memenuhi kewajiban atau membayar utang jangka pendeknya. Dengan kata lain, rasio likuiditas adalah rasio yang dapat digunakan untuk mengukur sampai seberapa jauh tingkat kemampuan perusahaan dalam melunasi kewajiban jangka pendeknya yang akan segera jatuh tempo. Suyanto dan Supramono (2012) menyatakan bahwa likuiditas sebuah perusahaan diprediksi akan mempengaruhi agresivitas pajak perusahaan. Perusahaan yang memiliki likuiditas tinggi menggambarkan arus kas yang baik sehingga perusahaan tersebut tidak enggan untuk membayar seluruh kewajibannya termasuk membayar pajak. 


\section{Hubungan Kepemilikan Manajerial Terhadap Agresivitas Pajak}

Semakin besar proporsi kepemilikan manajerial dalam perusahaan maka manajemen akan berusaha lebih giat untuk kepentingan pemegang saham yang notabene adalah mereka sendiri (Putu, 2003:3).

Jika dalam struktur kepemilikan perusahaan dimiliki oleh kepemilikan manajerial, maka manajer akan berupaya mengambil langkah-langkah untuk mengurangi kewajiban pajak perusahaan selama beberapa tahun (Mahentiran dan Kasipilai, 2012).

Jika dalam struktur kepemilikan perusahaan dimiliki oleh kepemilikan manajerial, maka manajer akan merasakan langsung dampak dari keputusan yang diambil dan manajer juga akan menanggung resiko apabila ada kerugian yang timbul sebagai konsekuensi dari pengambilan keputusan. Ketika kepemilikan manajerial perusahaan tinggi, manajer cenderung akan meningkatkan laba dan melakukan perencanaan pajak yang baik untuk menurunkan effective tax rate (ETR) perusahaan.

\section{Hubungan Kepemilikan Institusional Terhadap Agresivitas Pajak}

Kepemilikan institusional pemegang saham mampu mengoptimalkan pengawasan kinerja manajemen dengan memonitoring setiap keputusan yang diambil oleh pihak manajemen selaku pengelola perusahaan. Semakin besar proporsi saham yang dimiliki oleh institusional membuat pengawasan terhadap manajemen juga akan meningkat. Hal tersebut membuat pemegang saham akan berusaha sebisa mungkin mengarahkan perusahaan untuk melakukan perencanaan pajak yang baik untuk menurunkan effective tax rate (ETR) perusahaan.

\section{Hubungan Likuiditas Terhadap Agresivitas Pajak}

Perusahaan yang likuid adalah perusahaan yang mampu membayar hutangnya. Perusahaan akan berusaha keras untuk memenuhi kewajibannya secara tepat waktu. Manajer akan berusaha meningkatkan laba untuk membayar hutang beserta bunga dan administrasinya. Beban bunga ini dapat mengurangi penghasilan kena pajak. Hal ini menjadi celah bagi perusahaan melakukan pajak yang agresif dengan membuat kebijakan hutang yang besar. Sehingga likuiditas suatu perusahaan dapat mempengaruhi terjadinya pajak yang agresif.

\section{METODOLOGI PENELITIAN}

\section{Populasi dan Sampel}

Populasi adalah kejadian atau segala sesuatu yang memiliki karakteristik tertentu. Populasi juga dapat diartikan sebagai ojek atau subjek yang mempunyai kualitas dan karakteristik tertentu yang diterapkan oleh peneliti untuk dipelajari dan kemudian ditarik kesimpulannya. Populasi yang akan menjadi objek dalam penelitian ini adalah 
seluruh perusahaan manufaktur yang terdaftar di Bursa Efek Indonesia (BEI) periode 2015-2017. Populasi yang dikaitkan dengan kriteria penelitian menghasilkan sampel.

\section{Jenis Data}

Data yang digunakan dalam penelitian ini adalah data sekunder. Data sekunder adalah data dari perusahaan yang telah siap diolah sesuai dengan kebutuhan pemakai informasi. Pada penelitian ini, data yang digunakan adalah laporan keuangan perusahaan manufaktur yang terdaftar di Bursa Efek Indonesia (BEI) Periode 20152017, dimana datanya lebih terpercaya keabsahannya karena telah diperiksa oleh akuntan independen.

\section{Pengumpulan Data}

Pengumpulan data penelitian berupa metode penelitian lapangan (Field Research) dan metode penelitian kepustakaan (Library Research).

\section{Variabel Penelitian}

\section{Variabel Dependen (Y)}

Variabel dependen adalah variabel yang dipengaruhi oleh variabel independen. Variabel dependen dalam penelitian ini adalah agresivitas pajak.

\section{Variabrel Independen (X)}

Variabel-variabel independen $(\mathrm{X})$ atau variabel bebas adalah variabel yang dipengaruhi variabel lainnya. Variabel independen yang digunakan dalam penelitian ini adalah kepemilikan manajerial (X1), kepemilikan institusional (X2) dan likuiditas (X3).

\section{Hipotesis}

\section{Pengaruh Kepemilikan Manajerial terhadap Agresivitas Pajak}

Kepemilikan manajerial seharusnya tidak mementingkan dirinya sendiri namun tetap memperhatikan pertumbuhan perusahaan dengan tidak melakukan pajak yang agresif. Maka dapat ditarik kesimpulan bahwa kepemilikan manajerial memiliki pengaruh terhadap pajak secara agresif

Beberapa hasil penelitian diantaranya penelitian Rahati (2015) menyatakan bahwa kepemilikan manajerial berpengaruh terhadap tarif pajak efektif. Hasil yang berbeda mengenai pengaruh kepemilikan manajerial terhadap effective tax rate ditunjukkan oleh Citra \& Maya (2016) yang menyatakan bahwa kepemilikan manajerial tidak berpengaruh terhadap effective tax rate (ETR).

$\mathrm{H}_{0}$ : Kepemilikan Manajerial tidak berpengaruh terhadap Effective Tax Rate (ETR) 


\section{Pengaruh Kepemilikan Institusional terhadap agresivitas pajak}

Kepemilikan institusional dalam struktur kepemilikan memiliki peran monitoring management. Semakin tinggi kepemilikan oleh pihak institusional maka akan semakin kuat eksternal control terhadap perusahaan,atau akan semakin besar dorongan pihak institusi untuk mengawasi manajemen.Pengontrolan yang kuat membuat perusahaan patuh akan peraturan perundang - undangan termasuk peraturan pajak. Sehingga kepemilihan istitusional dapat mencegah terjadinya pajak yang agresif.

Berdasarkan pemikiran diatas dan didukung oleh beberapa hasil penelitian diantaranya penelitian yang dilakukan oleh Citra \& Maya (2016) dan Rahati (2015) yang menyatakan bahwa kepemilikan institusional tidak berpengaruh terhadap effective tax rate (ETR). Sedangkan penelitian yang dilakukan oleh Lisnawati dan Icha (2018) menyatakan bahwa kepemilikan institusional berpengaruh terhadap effective tax rate (ETR).

$\mathrm{H}_{0}$ : Kepemilikan Institusional tidak berpengaruh terhadap Effective TaRate (ETR)

\section{Pengaruh Likuiditas Terhadap Agresivitas Pajak}

Perusahaan akan berusaha meningkatkan laba untuk membayar hutang beserta bunga dan administrasinya. Beban bunga ini dapat mengurangi penghasilan kena pajak. Beban bunga dapat dijadikan celah untuk mengurangi PKP sehingga perusahaan akan cenderung untuk mencari dana dari luar selain dapat membantu memperbesar perusahaan namun juga dapat mengecilkan PKP. Maka dapat ditarik kesimpulan bahwa likuiditas dapat mempengaruhi agresivitas pajak.

Beberapa hasil penelitian. Indrajati (2017) menyimpulkan bahwa Likuiditas berpengaruh signifikan terhadap Agresivitas pajak, sedangkan penelitian Dita Yuliawati dan Pratama Hidayat Dani Sopian (2016) yang menyimpulkan bahwa Likuiditas tidak berpengaruh terhadap Agresivitas Pajak.

$\mathrm{H}_{0}$ : Likuiditas tidak berpengaruh terhadap agresivitas pajak.

\section{Variabel dan Skala Pengukuran}

Penelitian ini menggunakan variabel bebas (independent) dan variabel terikat (dependent). Variabel bebas pada penelitian ini adalah Kepemilikan Manajerial, Kepemilikan Institusional dan Likuiditas. Variabel terikat dalam penelitian ini adalah Effective Tax Rate (ETR).

1. Variabel Bebas atau Independent Variable (X) merupakan variabel yang dapat mempengaruhi atau menjadi sebab perubahan atau timbulnya dependent variable atau variabel terikat (Y). Variabel bebas pada penelitian ini adalah Kepemilikan Manajerial, Kepemilikan Institusional dan Likuiditas.

a. Kepemikan Manajerial 
Kepemilikan manajerial menunjukkan persentase kepemilikan saham yang dimiliki oleh pihak manajemen yang terdiri dari dewan direksi dan dewan komisaris dalam sebuah perusahaan. Kepemilikan manajerial merupakan proporsi saham biasa yang dimiliki oleh pihak manajemen yang secara aktif terlibat dalam pengambilan keputusan perusahaan. Kepemilikan manajerial diukur dengan membagi saham atas kepemilikan manajemen dengan total saham (Sudarma, 2003 dalam Citra dan Maya, 2016):

b. Kepemilikan Institusional

Kepemilikan institusional merupakan jumlah saham perusahaan yang dimiliki oleh pihak institusi atau lembaga. Kepemilikan institusional diukur dengan membagi saham yang dimiliki oleh institusi dengan total saham (Sudarma, 2003 dalam Citra dan Maya, 2016):

c. Likuiditas

Likuiditas adalah kemampuan perusahaan dalam memenuhi kewajiban jangka pendek.

2. Variabel Terikat atau Dependent Variable (Y) merupakan variabel yang dipengaruhi atau menjadi akibat karena adanya independent variable atau variabel bebas (X). Variabel terikat dalam penelitian ini adalah agresivitas pajak yang diproksikan dengan Effective Tax Rate (ETR). Dihitung dari total beban pajak penghasilan (beban pajak kini ditambah dengan beban pajak tangguhan) dibagi dengan laba sebelum pajak (Rodriguez dan Arias, 2012 dalam Citra dan Maya, 2016).

\section{ANALISIS HASIL DAN PEMBAHASAN}

\section{Deskripsi Objek Penelitian}

\section{Gambaran Umum}

Penelitian ini meneliti pada perusahaan - perusahaan yang terdaftar di Bursa Efek Indonesia. Untuk melihat apakah terdapat pengaruh kepemilkan manajerial, kepemilikan institusional dan likuiditas terrhadap pengurangan pajak secara agresif. Perusahaan - perusahaan yang masuk dalam penelitian ini adalah perusahaan manufaktur pada periode 2015-2017.

\section{Populasi dan Sampel}

Selama tahun 2015-2017 terdapat 445 perusahaan manufaktur yang terdaftar di Bursa Efek Indonesia. Perusahaan manufaktur yang akan dijadikan sampel harus melalui proses seleksi berdasarkan kriteria yang telah ditentukan terlebih dahulu yang dalam penelitian ini menggunakan metode purposive sampling dengan kriteria-kriteria penelitian sebagai berikut:

1. Perusahaan manufaktur yang terdaftar di Bursa Efek Indonesia tahun 2015 sampai 2017

2. Laporan keuangan menggunakan mata uang rupiah 
3. Perusahaan memperoleh laba selama tahun pengamatan

4. Data laporan keuangan perusahaan dan data untuk perhitungan variabel tersedia secara lengkap untuk tahun pelaporan 2015 sampai 2017

\section{Analisa Deskriptif}

Statistik deskrptif dilakukan untuk menunjukkan jumlah data (N) yang digunakan dalam penelitian ini serta untuk menunjukkan nilai maksimum, nilai minimum, nilai rata-rata (mean), dan standar deviasi $(\alpha)$ dari masing-masing variabel yang dimiliki oleh perusahaan konsumsi yang menjadi objek penelitian. Dalam penilitan ini menguji pengaruh variabel independen yang diproksikan ke dalam Kepemilikan manajerian, kepemilikan institusional dan likuidasi terhadap agresivitas pajak sebagai variabel dependen.

Table Diskriptif

Descriptive Statistics

\begin{tabular}{|l|r|r|r|r|r|}
\hline & $\mathrm{N}$ & Minimum & Maximum & Mean & Std. Deviation \\
\hline Kepemilikan Manajerial & 113 &, 04 &, 66 &, 3365 &, 13294 \\
Kepemilikan Institusional & 113 &, 00 &, 38 &, 1135 &, 10970 \\
Likuiditas & 113 &, 51 & 1,00 &, 8612 &, 14334 \\
Agresivitas pajak & 113 &, 16 &, 31 &, 2442 &, 03637 \\
Valid N (listwise) & 113 & & & & \\
\hline
\end{tabular}

Sumber: Data diolah,2019.

\section{Koefisien Determinasi $\left(R^{2}\right)$}

Koefisien determinasi $R^{2}$ bertujuan untuk mengukur seberapa jauh kemampuan model dapat menerangkan variasi variabel.

\section{R-Square pada Model Summary}

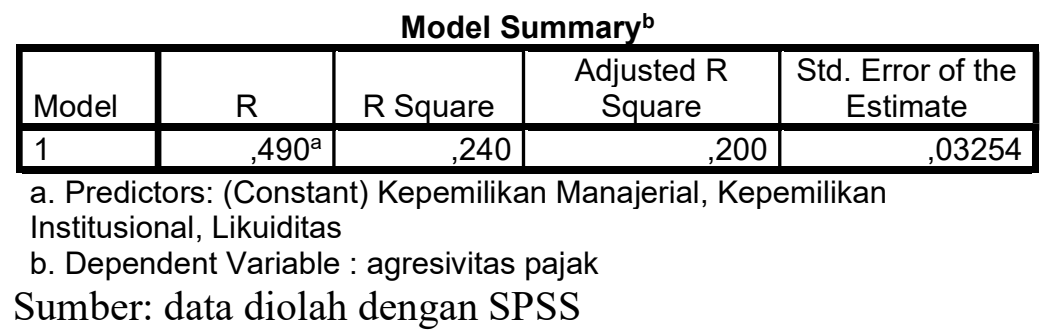

\section{Uji Parsial (Uji t)}

Digunakan untuk membuktikan pengaruh variabel independen terhadap variabel dependen secara individu atau parsial. Untuk melihat hasil pengujian dapat dilihat pada table dibawah ini. 
Hasil uji partial pada penelitian ini:

1. Kepemilikan manajerial

Hasil pengujian statistik menunjukkan bahwa variable kepemilikan manajerial mempunyai nilai signifikansi sebesar 0,383 dengan koefisien regresi sebesar 0,039 . Hal ini menunjukkan bahwa " tidak ada pengaruh kepemilikan manajerial terhadap agresivitas pajak pada perusahaan manufaktur 2015-2017". Hal ini menyatakan bahwa $\mathrm{H}_{0}$ diterima

2. Kepemilikan institusional

Hasil pengujian statistik menunjukkan bahwa variable kepemilikan institusional mempunyai nilai signifikansi sebesar 0,00 dengan koefisien regresi sebesar -0,376. Hal ini menunjukkan bahwa " ada pengaruh kepemilikan institusional terhadap agresivitas pajak pada perusahaan manufaktur 20152017'. Hal ini menyatakan bahwa $\mathrm{Ha} 2$ diterima

\section{Likuiditas}

Hasil pengujian statistik menunjukkan bahwa variable likuiditas mempunyai nilai signifikansi sebesar 0,001 dengan koefisien regresi sebesar 0,252 . Hal ini menunjukkan bahwa " ada pengaruh likuiditas terhadap agresivitas pajak pada perusahaan manufaktur 2015-2017'. Hal ini menyatakan bahwa Ha3 diterima.

\section{Persamaan Regresi Linier Berganda}

Hasil uji koefisen regresi dapat dilihat pada tabel 4.10 tabel tersebut menunjukkan hasil pengujian dengan regresi pada tingkat signifikan 0,05

\section{Uji Koefisien Regresi}

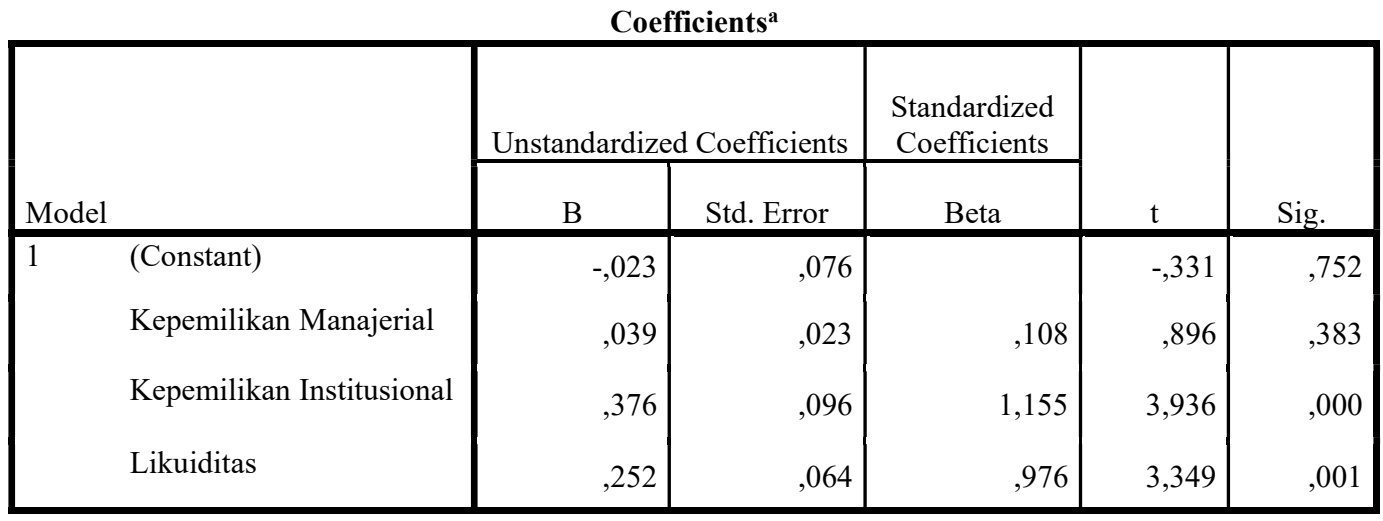

a. Dependent Variable: Agresivitas pajak

Sumber: Data diolah, 2019. 
Berdasarkan tabel diatas maka dapat disusun persamaan regresi berganda sebagai berikut :

$$
Y=-\mathbf{0 , 0 2 3}+\mathbf{0 , 0 3 9} X_{1}+\mathbf{0 , 3 7 6} X_{2}+\mathbf{0 , 2 5 2} X_{3}+\mathbf{e}
$$

\section{Pembahasan dan Interprestasi}

\section{Hasil Penelitian Dengan Landasan Teori}

\section{Pengaruh Kepemilikan Manajerial Terhadap Agresivitas Pajak}

Hasil pengujian statistik menunjukkan bahwa kepemilikan manajerial tidak berpengaruh signifikan terhadap agresivitas pajak. Hal ini dapat terlihat dari nilai signifikansi kepemilikan manajerial 0,383 lebih besar dari $\alpha=0,05$. Disimpulkan bahwa $\mathrm{H}_{0}$ diterima. Tidak berpengaruhnya kepentingan manajerial terhadap agresivitas pajak

\section{Pengaruh Kepemilikan Institusional Terhadap Agresivitas Pajak}

Hasil pengujian statistik menunjukkan bahwa kepemilikan institusional berpengaruh signifikan terhadap agresivitas pajak. Hal ini dapat terlihat dari nilai signifikansi kepemilikan institusional 0,000 lebih kecil dari $\alpha=0,05$. Disimpulkan bahwa $\mathrm{H}_{0}$ ditolak. Kepemilikan institusional berpengaruh terhadap agresivitas pajak.

\section{Pengaruh likuiditas terhadap agresivitas pajak}

Hasil pengujian statistik menunjukkan bahwa likuiditas berpengaruh signifikan terhadap agresivitas pajak. Hal ini dapat terlihat dari nilai signifikansi 0,01 lebih kecil dari $\alpha=0,05$. Disimpulkan bahwa $\mathrm{H}_{0}$ ditolak

Hal ini membuktikan bahwa likuiditas berpengaruh signifikan terhadap agresivitas pajak.

\section{KESIMPULAN DAN SARAN}

\section{Kesimpulan}

1. Tidak ada pengaruh kepemilikan manajerial terhadap agresivitas pajak pada perusahaan manufaktur yang terdaftar di BEI tahun 2015-2017.

2. Terdapat pengaruh kepemilikan institusional terhadap agresivitas pajak perusahaan manufaktur yang terdaftar di BEI tahun 2015-2017.

3. Terdapat pengaruh likuiditas terhadap agresivitas pajak perusahaan manufaktur yang terdaftar di BEI tahun 2015-2017.

\section{Saran}

1. Pengujian yang dilakukan pada tiga periode waktu yang terbatas yaitu periode 2015 sampai dengan 201 7. Sehingga hasil penelitian ini tidak dapat digunakan 
untuk melihat kecenderungan dalam jangka panjang, oleh sebab itu disarankan yang lebih variatif dengan jumlah yang lebih banyak sehingga dihasilkan kesimpulan yang valid.

2. Keterbatasan dalam penelitian ini adalah hanya menggunakan 3 variabel independen yaitu kepemilikan manajerial, kepemilikan institusional dan likuiditas . Oleh sebab itu, untuk penelitian selanjutnya disarankan untuk menambahkan variabel lain yang memungkinkan dapat melihat faktor-faktor lain yang mempengaruhi agresivitas pajak.

\section{DAFTAR PUSTAKA}

\section{$\underline{\text { Buku : }}$}

Fitrios, Ruhul dan Rusli, 2007. Pengantar Hukum Pajak. Pekanbaru: Unri Press.

Ghozali, Imam. 2016. Aplikasi Analisis Multivariete IBM SPSS 23. Edisi 8. Semarang : Universitas Diponegoro.

Hadi, Nor. 2011. Corporate Social Responsibility. Edisi Pertama. Yogyakarta : Graha Ilmu.

Hery. 2016. Analisis Laporan Keuangan. Jakarta : Gramedia Widiasarana Indonesia.

Ilyas, B, Wirawan. 2010. Hukum Pajak. Edisi 5. Jakarta : Salemba Empat.

Mardiasmo, 2016. Perpajakan. Edisi Revisi 2016. Yogyakarta : Andi.

Pohan, Anwar, Chairil. 2015. Manajemen Perpajakan Strategi Perencanaan Pajak dan Bisnis. Jakarta : PT Gramedia Pustaka Utama.

Rahmawati. 2012. Teori Akuntansi Keuangan. Yogyakarta: Graha Ilmu.

Rocmat Soemitra, Dewo Karina Sugiharti, Asas dan Dasar Perpajakan, 2010.

\section{Jurnal :}

Ardyansyah, Danis dan Aunalal (2014). Pengaruh Size, Leverage, Profitability, Capital Intensity Ratio dan Komisaris Independen Terhadap Effective Tax Rate (ETR). Fakultas Ekonomika Dan Bisnis Universitas Diponegoro. Semarang.

Azzahra, Dita, Reminda. 2017. Pengaruh Corporate Social Responsibility, Profitabilitas, Ukuran Perusahaan dan Capital Intensity Terhadap Agresivitas Pajak (Studi Empiris pada Perusahaan Perbankan yang terdaftar di BEI Periode Tahun 2013 - 2015). Pekanbaru : Fakultas Ekonomi Universitas Riau, Vol.4 No.2. 
Besley, S. dan E.F. Brigham. 2007. Essentials of Manajerial Finance. US: SouthWestern Pub. JOM Fekon, Vol.3 No.1 (Februari) 20161149.

Dewi Nawang Gemilang. 2017. Pengaruh Likuiditas, Leverage, Profitabilitas, Ukuran Perusahaan dan Capital Intensity Terhadap Agresivitas Pajak Perusahaan (Studi Empiris Pada Perusahaan Property dan Real Estate yang Terdaftar di BEI Pada Tahun 2013 - 2015). Surakarta : Fakultas Ekonomi dan Bisnis Islam.

Dita, Yuliawati, Pratama Hidayat, Dani Sopian. 2016. Pengaruh Ukuran Perusahaan, Likuiditas dan Profitabilitas Terhadap Agresivitas Pajak (Studi Pada Perusahaan Otomotif yang Terdaftar di BEI Periode 2011 - 2014). Vol VIII No. 2/ November/2016.

Eksandy, Arry. 2017. Pengaruh Komisaris Independen, Komite Audit dan Kualitas Audit Terhadap Penghindaran Pajak (Tax Avoidance) (Studi Empiris Pada Sektor Industri Barang Konsumsi yang Terdaftar di Bursa Efek Indonesia Periode 2010-2014). Competitive Journal Vol.1 No.1. Januari - Juni 2017. Fakultas Ekonomi dan Bisnis Universitas Muhammadiyah Tangerang.

Fatharani, Nazhaira. 2012. Pengaruh Karakteristik Kepemilikan, Reformasi Perpajakan dan Hubungan Politik Terhadap Tindakan Pajak Agresif Pada Perusahaan yang Terdaftar Dibursa Efek Indonesia Pada Tahun 2007 - 2010. Skripsi Dipublikasikan. Universitas Indonesia.

Frank, M., Lynch, L., dan Rego, S. 2009. "Tax Reporting Aggressiveness and its Relation to Aggressiveness Financial Reporting”. The Accounting Review. Vol. 84, Hal 467 - 496.

Indrajati, D., Djumena, S., \& Yuniarwati. (2015). Faktor-Faktor Yang Mempengaruhi Aresivitas Pajak Pada Perusahaan Manufaktur yang Terdaftar di BEI 2013 2015. Jurnal Muara Ilmu Ekonomi Dan Bisnis, 1(1), 125-134.

Jensen, M. and Meckling, W. (1976), "Theory of the firm: Managerial Behaviour, agency costs and ownership structure”, Journal of Financial Economics 3 (4), 305-360.

Marfu'ah. 2015. Pengaruh Return On Assets, Leverage, Ukuran Perusahaan Kompensasirugi Fiskal dan Koneksi Politik Terhadap Tax Avoidance. Skripsi. Universitas Muhammadiyah Surakarta. Surakarta.

Mustika. 2017. Pengaruh Corporate Socal Responsibility, Ukuran Perusahaan, Profitabilitas, Leverage, Capital Intensity dan Kepemilikan Keluarga Terhadap Agresivitas Pajak (Studi Empiris pada Perusahaan Pertambangan dan Pertanian yang Terdaftar di Bursa Efek Indonesia Periode Tahun 20122014). Pekanbaru : Fakultas Ekonomi Universitas Riau, Vol. 4 No. 1.

Lanis, R., dan Richardson, G. 2012. Corporate Social Responsibility and Tax Aggressiveness: An Emperical Analysis. Jurnal Of Accounting and Public Policy, 31. Hal: $86-108$. 
Nugraha, Novia Bani. 2015. Pengaruh Corporate Social Responsibility, Ukuran Perusahaan, Profitabilitas, Laverage dan Capital Intensity Terhadap Agresivitas Pajak. Diponegoro : Journal Of Accounting, Vol. 4.

Putu Ayu Seri Andhari, I Made Sukartha. 2017. Pengaruh Pengungkapan Corporate Social Responsibility, Profitabilitas, Inventory Intensity, Capital Intensity dan Laverage Pada Agresivitas Pajak. Bali : Fakultas Ekonomi dan Bisnis Universitas Udayana (Unud), Vol. 18.3.

Putu Meita Prasista, Ery Setiawan. 2016. Pengaruh Profitabilitas dan Pengungkapan Corporate Social Responsibility Terhadap Agresivitas Pajak Pengahasilan Wajib Pajak Badan. Bali : Fakultas Ekonomi dan Bisnis Universitas Udayana (Unud), Vol. 17.3.

Sari, Anngita. 2012. Pengaruh Karakteristik Perusahaan Terhadap Corporate Social Responsibility Disclosure. Universitas Negeri Yogyakarta, Volume 1.

Suyanto, Krisnata Dwi. 2012. Pengaruh Likuidita, Leverage, Komisaris Independen dan Manajemen Laba Terhadap Agresivitas Pajak Perusahaan. Tesis, Pascasarjana Universitas Kristen Satya Wacana, Salatiga.

Suyanto, dan Supramono. 2012. Likuiditas, Leverage, Komisaris Independen dan Manajemen Laba Terhadap Agresivitas Pajak Perusahaan. Jurnal Keuangan dan Perbankan. Vol. 16, No. 2. 